\title{
Optimum Design Parameters of Box Window DSF Office at Different Glazing Types under Sub Interval of Intermediate Sky Conditions (20-40 klux)
}

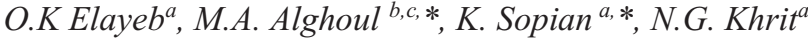 \\ ${ }^{a}$ Solar Energy Research Institute, Universiti Kebangsaan Malaysia, 43600 Bangi, Selangor, Malaysia \\ ${ }^{b}$ Energy and Building Research Center, Kuwait Institute for Scientific Research, P.O. Box 24885, Safat 13109, \\ Kuwait \\ ${ }^{c}$ Center of Research Excellence in Renewable Energy (CoRe-RE), Research Institute, King Fahd University of \\ Petroleum and Minerals (KFUPM), Dhahran 31261, Saudi Arabia
}

*Corresponding authors: dr.alghoul@gmail.com (M.A.Alghoul), ksopian@ukm.edu.my (K. Sopian)

\begin{abstract}
:
Despite Double skin façade (DSF) buildings are widely deployed worldwide, daylighting strategy is not commonly incorporated in these buildings compare to other strategies. Therefore, further theoretical and experimental studies would lead to adopting daylighting strategy in DSF office buildings. The aim of this study is to investigate the daylighting performance of office building at different design parameters of box window DSF using different glazing types under sub interval of intermediate sky conditions (20-40) klux using the (IES VE) simulation tool from Integrated Environmental Solutions - Virtual Environment. The implemented design parameters are window wall ratio (WWR) of internal façade (10-100) \%, cavity depth (CD) of DSF (1-2.5) m and different glazing types. The glazing types were selected from the list available in the (IES VE) simulation tool. After series of evaluations, bronze tinted coating (STOPSOL) is implemented for the exterior façade while clear float, clear reflective coating (STOPSOL), grey and brown tinted coating (Anti-sun float) and blue coating tinted (SUNCOOL float) are implemented for the interior façade. In this paper, several evaluation parameters are used to quantify the optimum design parameters that would balance the daylighting requirements of a box window DSF office versus sky conditions range (20-40) klux. The optimum design parameters of DSF office building obtained under different glazing types are highlighted as follows. When using bronze tinted coating (STOPSOL) for the exterior façade, the glazing types of interior façade that showed superior daylighting performance of DSF office at (CD of $1.0 \mathrm{~m}$ with WWR of 70\%), (CD of $1.5 \mathrm{~m}$ with WWR of 70\%), (CD of $2.0 \mathrm{~m}$ with WWR of $70 \%$ ) and (CD of $2.0 \mathrm{~m}$ with WWR of $70 \%$ ) are grey tinted coating (Anti-sun float), clear reflective coating (STOPSOL), brown tinted coating (Anti-sun float), and clear float glazing respectively. Blue Coating tinted (SUNCOOL float) of interior façade glazing failed to meet outstanding daylighting performance at any cavity depth.
\end{abstract}

Keywords: sub interval of intermediate sky conditions (20-40) klux, office building, box window DSF system, different glazing types, daylighting performance

Abbreviations

DSF Double Skin Façade

IES VE the Integrated Environmental Solutions - Virtual Environment simulation tool

CD Cavity Depth

WWR Window Wall Ratio

DF Daylight Factor

ADF Average Daylight Factor

UDI Useful Daylight Illuminance

\section{Introduction}

Full glazing façades are widely used for modern architectural projects, particularly commercial buildings, due to their aesthetics and daylight potential. In certain circumstances, single layer glass façades have common weaknesses such as poor thermal insulation and sound reduction index. To overcome these problems, application of DSFs is widely accepted to reduce energy consumption and thus to improve the sustainability of buildings [1]. Double-skin facades had been defined as multiple layer skins construction with an external skin, an intermediate space and an inner skin. The external and internal skins could be of either single glaze or double 
glazed glass panes and it generally could be grouped under Box Window facade, Shaft-box facade, Corridor facade and Multi-story façade [2].

Daylighting can influence the task involvement, productivity, mood and health and comfort therefore is a critical factor in office design in the commercial buildings [3]. At a time when the daylight technology is applied to reduce energy cost in lighting sector, it must be considered some of factors have an impact on daylighting performance such as, location of building, time, climate, size and material of window [4]. Windows are a serious factor in building energy, because thermal energy that is transferred through their transparent surface is crucial, and help to transfer natural daylight deep into building. During summer, windows allow heat to pass in the building and during winter, heat escapes and variable light transmission of daylight allows the presence of a solar gain and glare $[5,6]$ It is estimated that windows are responsible for $60 \%$ of the total building energy losses. Hence, improvement of the performance for windows with low thermal transmittance can virtually contribute in reducing energy costs of buildings, and can provide large energy savings [6].

In the modern windows, the use of two or three panes together with different selective coatings is very common. This leads to increase the use of artificial light and gives darker appearance to the window but using an antireflection coating can be increases the transmittance of daylight leading to a brighter window. The optical properties of a glazing are commonly summarized in transmittance of daylight (Tvis), transmittance of all solar radiation (Tsol) and the g-value [7]. Although the changing from a high to a low transmittance glazing reduces energy savings for the office and the UDI value increases with low transmittance glazing, but it decreases with increasing WWR and reduces visual comfort in a indoor environment [8]. Daylighting under clear and intermediate sky condition often is accompanied by high temperature and glare. To limit depleting energy and improve performance of the window system, there are a wide variety of different types of glass in the market that can be used to reach this goal.

\section{Materials and methods}

\subsection{Model description and materials used}

The box window DSF office is used for daylighting simulations with $\mathrm{CD}$, adjustable internal façade opening, and different glazing types. The study is performed in a simulated office with dimensions of $4 \mathrm{~m}$ in width, $6 \mathrm{~m}$ in depth and $3 \mathrm{~m}$ in height, located at a height of $16 \mathrm{~m}$ over the floor of a building with south orientation. These models are double glazed facades with a cavity depth of 1, 1.5, 2.0 and 2.5, respectively. Ten window sizes are modeled with fenestration window-to-wall area ratios. The light reflectance of the ceiling, wall and floor of the model is $0.7,0.5$ and 0.2 respectively. The exterior façade openings for a box window DSF is full glass. A bronze tinted coating (STOPSOL) is implemented for the exterior façade. The range of internal façade openings for a box window DSF (WWR 10-80\%) was covered in the analysis. The five glazing types to be used for the internal windows are determined with respect to its transmission, absorption and reflection for light. A grey (GI) and brown tinted coating (Anti-sun float) (G-II), blue coating tinted (SUNCOOL float 40/50) (G-III), clear float (G-IV) and clear reflective coating (STOPSOL) $(\mathrm{G}-\mathrm{V})$, are implemented for the interior façade. The glazing transmittance for an external window is $29 \%$, while the glazing transmittance for an internal window with using (G-I), (G-II), (G-III), (G-IV) and (G-V) is 42, 58, 32, 82 and 53\%, respectively.

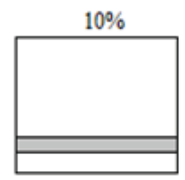

$50 \%$
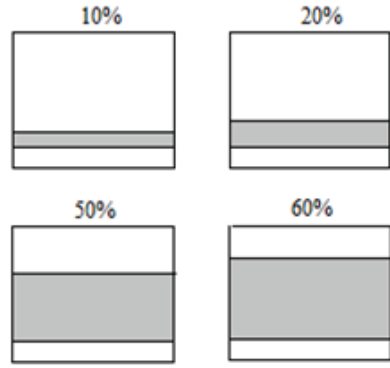

$60 \%$
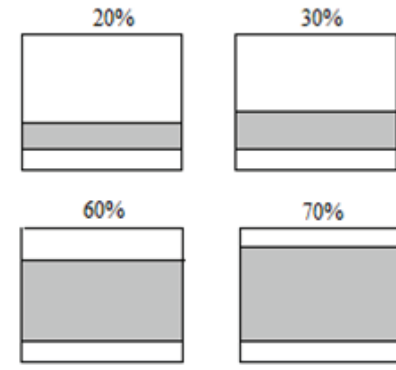

$70 \%$
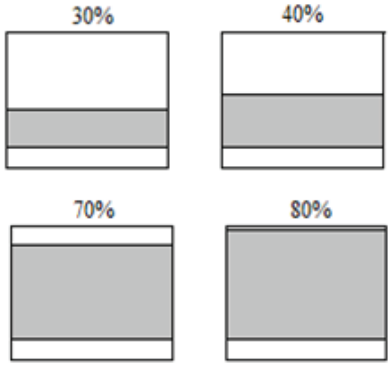

$80 \%$

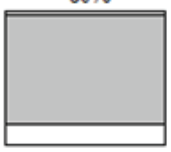

Fig 1: Implemented WWR of internal façade of DSF office 


\subsection{Method}

Integrated environmental solution $<$ Virtual Environment $>$ IES (VE) simulation tool is relatively unique amongst analysis tools which is intended to use during the earliest conceptual stages of design and provides daylighting calculations from first principles without any user programming. Therefore, in this study, this software was chosen and performed because it is widely used in building services and energy management industries. The indoor illuminance values are estimated at office table level $(0.70 \mathrm{~m})$ for all studied models under sky condition ranges $(20,30$ and $40 \mathrm{klux})$. To ensure the accuracy of simulation results, the IES-VE simulation software has been validated by comparing the simulation results to the experimental ones. A 1:10 scale model has been fitted from a wood "sandwich cardboard" with an internal size of $75 \mathrm{~cm}$ length, $40 \mathrm{~cm}$ in width, 30 height and thick 12 $\mathrm{mm}$. The external and internal walls were painted with white colour and light brown for the ceiling. The model was placed on a $1 \mathrm{~m}$ high platform of a roof top of SERI, UKM, Selangor, Malaysia, (N 2.92 ${ }^{\circ}$; E $\left.101.772^{\circ}\right)$ with $\mathrm{S}$ orientation. The office has been tested under the real sky conditions.

\section{Results and discussion}

Simulating the effect of different internal window glazing types was carried out to determine the optimum design parameters of DSF system of office buildings for daylighting performance under outdoor illuminance ranges between 20 to $40 \mathrm{klx}$. The average daylight factor (ADF) and average indoor illuminance inside the office for each DSF model were commonly used in early stages of design to estimate the daylighting characteristics and the required window area. The ADF must meet the requirements of Malaysian Standard MS ISO/IEC 17025:2005 which limited it between 1 and 6\%. Fig. 2 shows the methodology chart used to define and estimate the average indoor illuminance inside the office.

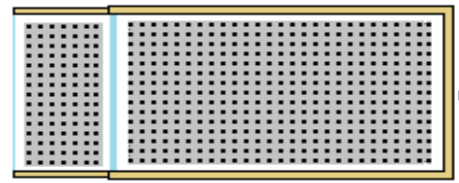

Sensor grid

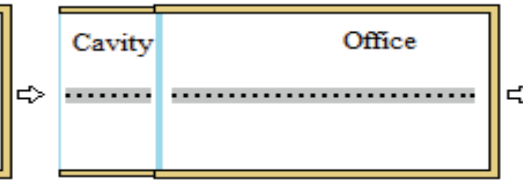

The average of each row

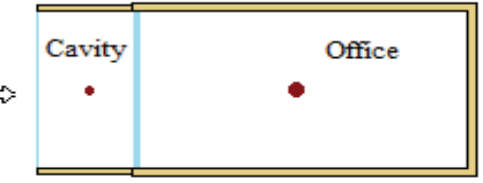

The average of the column

Fig 2: Method of determining and calculating of the mean office indoor illuminance values

In the cases the CD is $1.0 \mathrm{~m}$ and at $30,40,50,60,70$ and $80 \%$ WWR, the ADF is located mainly between $1-6 \%$ under outdoor illuminance (20,000-40,000 lx) for (G-I) and (G-II) and also under outdoor illuminance (20,000$30,000 \mathrm{~lx}$ ) for $(\mathrm{G}-\mathrm{I})$, (G-II) and $(\mathrm{G}-\mathrm{V})$. In addition, it is important to mention that the models with high transmittance of glazing window such as (G-IV), fail to meet the standard ADF, this requires that the CD must be more than $1.0 \mathrm{~m}$, as shown in Fig. 3. As seen in Fig. 4, in the cases CD is $1.5 \mathrm{~m}$ and at (20-80\%) WWR, the models only succeed to meet the standard ADF under outdoor illuminance (20-40 klx) with using (G-V), while under outdoor illuminance (20-30 klx) and at (30-80\%) WWR, the models succeed to meet the standard ADF for all types of implemented glazing window, except (G-IV) showed a ADF more than 6\% under outdoor illuminance $30 \mathrm{klx}$.
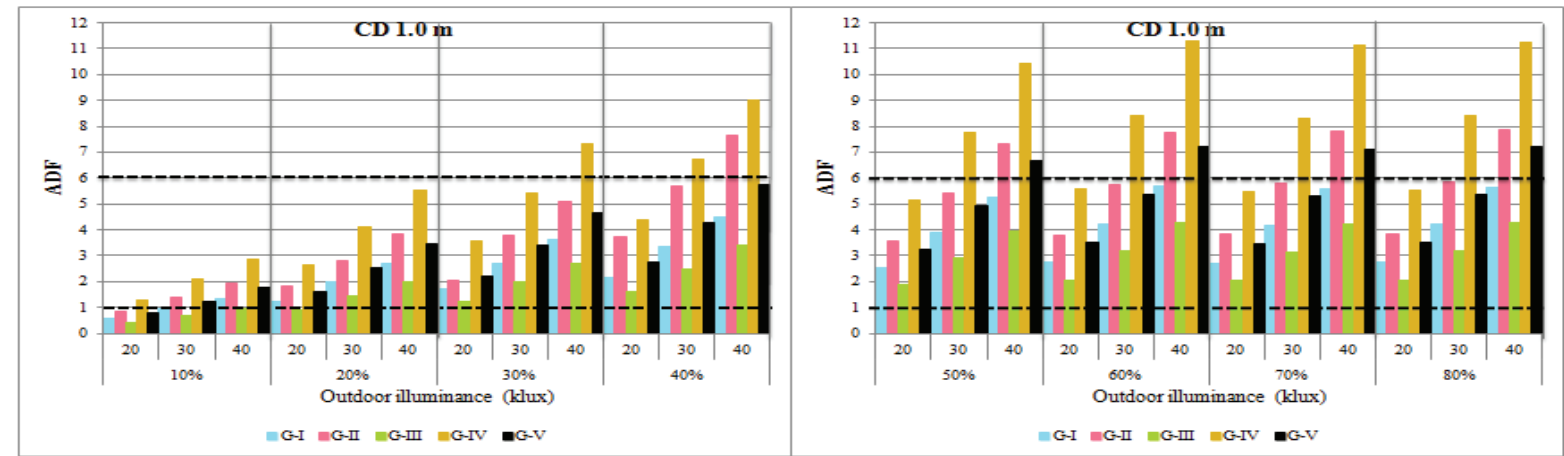

Fig 3: Average daylighting factor (ADF) versus outdoor illuminance (20-40klx) and different WWR at five types of implemented glazing window for CD $1.0 \mathrm{~m}$ 

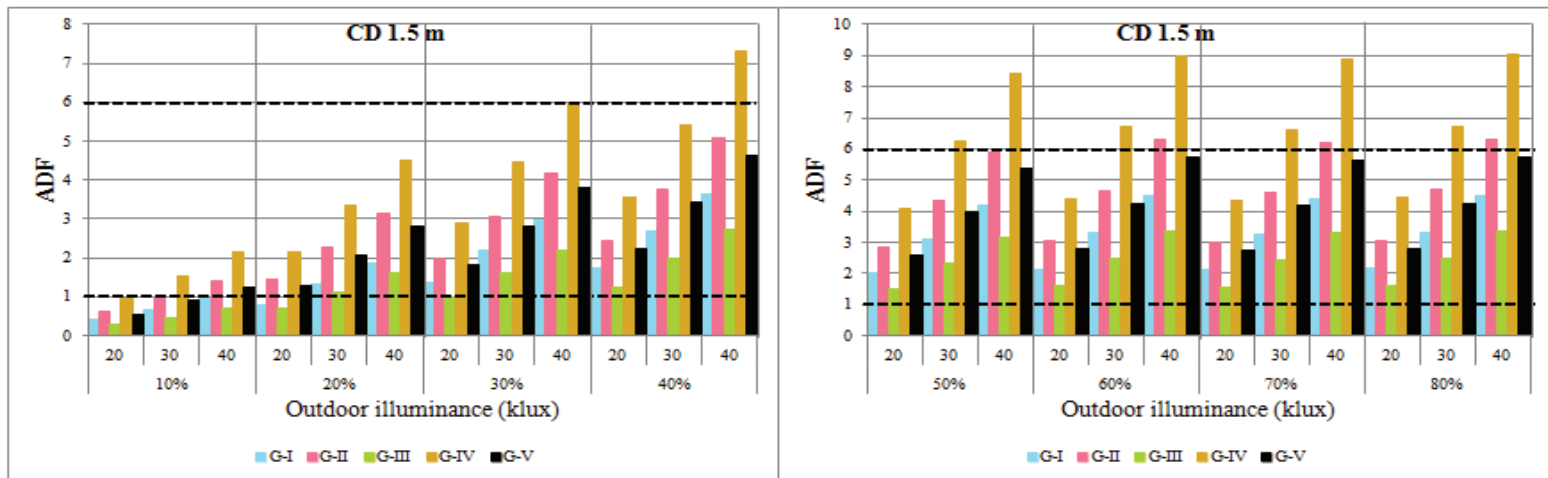

Fig 4: Average daylighting factor (ADF) versus outdoor illuminance (20-40klx) at different WWR and five types of implemented glazing window for CD $1.5 \mathrm{~m}$

Fig. 5 shows that with increasing the cavity depth to be $2.0 \mathrm{~m}$ and $2.5 \mathrm{~m}$, the indoor illuminance decreases inside the office, therefore, at (30-80\%) WWR, the ADF is located between 1-6\% under outdoor illuminance (20-40 klx) with (G-II), (G-IV) and (G-V). In the cases the CD is $2.5 \mathrm{~m}$ and at $(50-80 \%) \mathrm{WWR}$, the ADF is located between 1-6\% under outdoor illuminance (20-40 klx) with using all types of implemented glazing window (GV) (G-I) (G-II) (G-IV) and (G-V), while the glazing which has low transmittance in these the case, at (10-30\%) WWR, the ADF is less than a required minimum ADF under outdoor illuminance (20-30 klx), as shows in Figures 6.
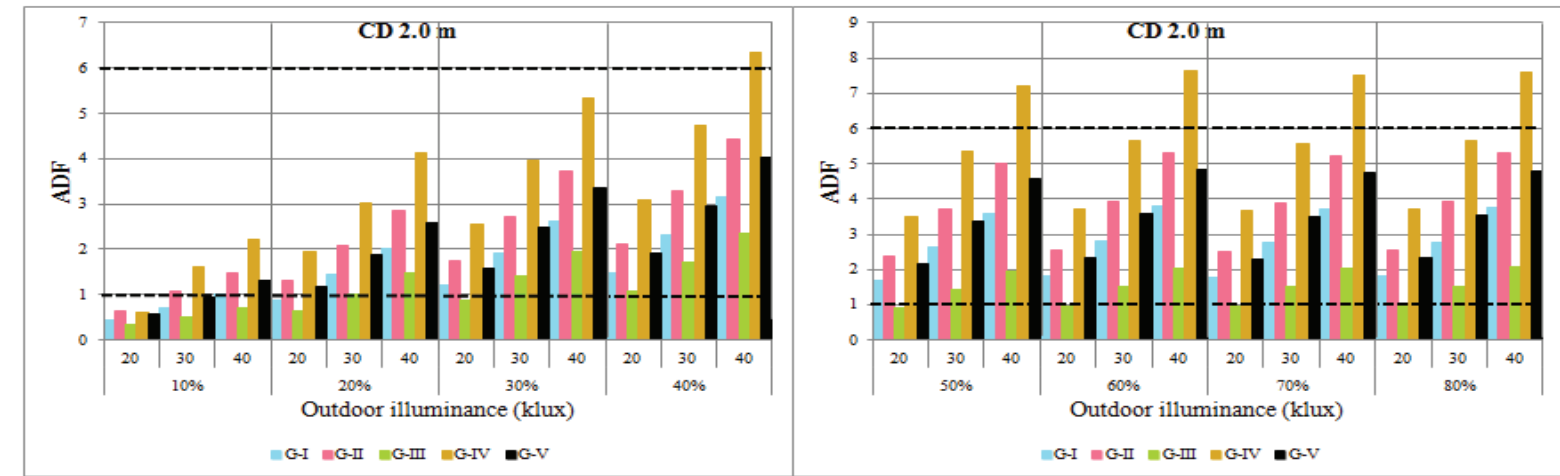

Fig 5: Average daylighting factor (ADF) versus outdoor illuminance (20-40klx) at different WWR and five types of implemented glazing window for CD $2.0 \mathrm{~m}$
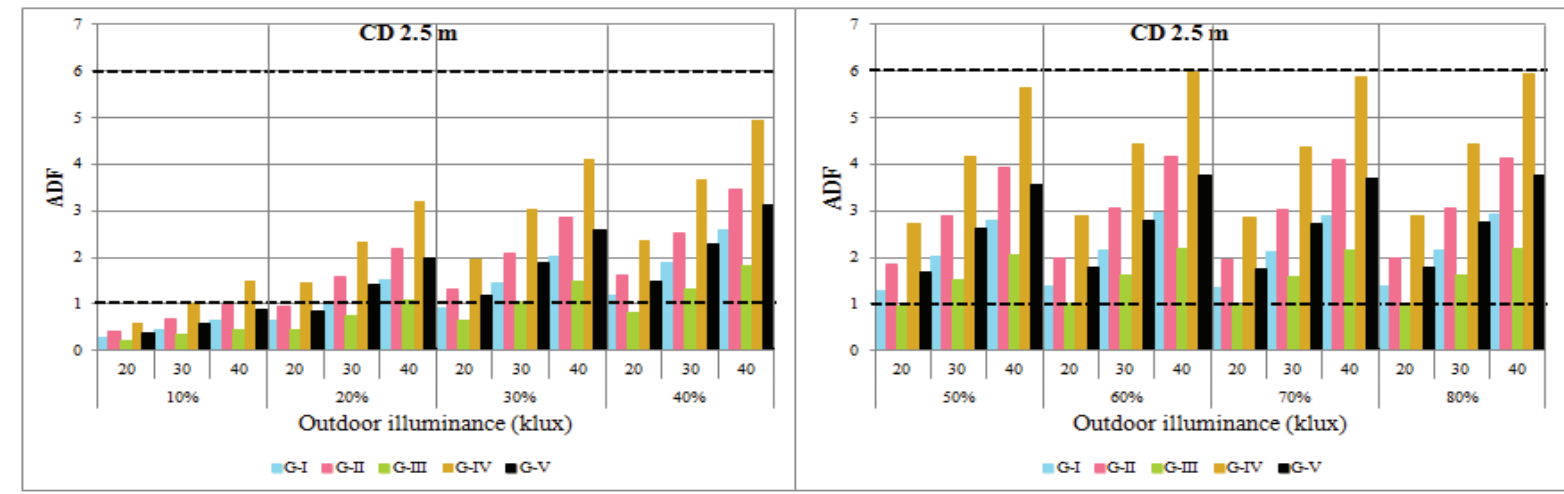

Fig 6: Average daylighting factor (ADF) versus outdoor illuminance (20-40klx) at different WWR for CD $2.5 \mathrm{~m}$ and five types of implemented glazing window 
The average indoor illuminance also must meet the requirements of Malaysian Standard MS ISO/IEC17025:2005 which limited it between 300 and 4001x in commercial offices. Figure 7, 8, 9 and 10 illustrate the average indoor illuminance of double skin façade DSF models versus outdoor illuminance (20-40 $\mathrm{klx}$ ) at a different window wall ratio WWR and cavity depth CD at five types of implemented glazing window. At CD 1.0m, the models have a recommended average indoor illuminance (300-400 lx) at a WWR range (60$80 \%$ ) with using (G-II) and (G-V) under outdoor illuminance $30 \mathrm{klx}$, while with using all the implemented types of glazing window the average indoor illuminance is less than 300lx under outdoor illuminance (20-30 klx) at WWR $10 \%$.

Also it can be noticed that the DSF model succeeds to reach to a recommended average indoor illuminance in the cases where the CD is $1.5 \mathrm{~m}$ at a WWR range between $(60-80 \%)$ under outdoor illuminance $30 \mathrm{klx}$ with using (G-I) only and under at a WWR of 40\% under outdoor illuminance $20 \mathrm{klx}$ with using (G-IV) and under outdoor illuminance $30 \mathrm{klx}$ with using (G-II) and (G-V). Increasing the cavity depth to be 2.0 and $2.5 \mathrm{~m}$, causes decreasing the average indoor illuminance inside the office, therefore, this requires using glazing has a high transmittance for high outdoor illuminance. In addition, the average indoor illuminance results when a WWR between $(60-80 \%)$ is found with values that are almost similar with using same type of glazing as seen in the figures referred to previously.
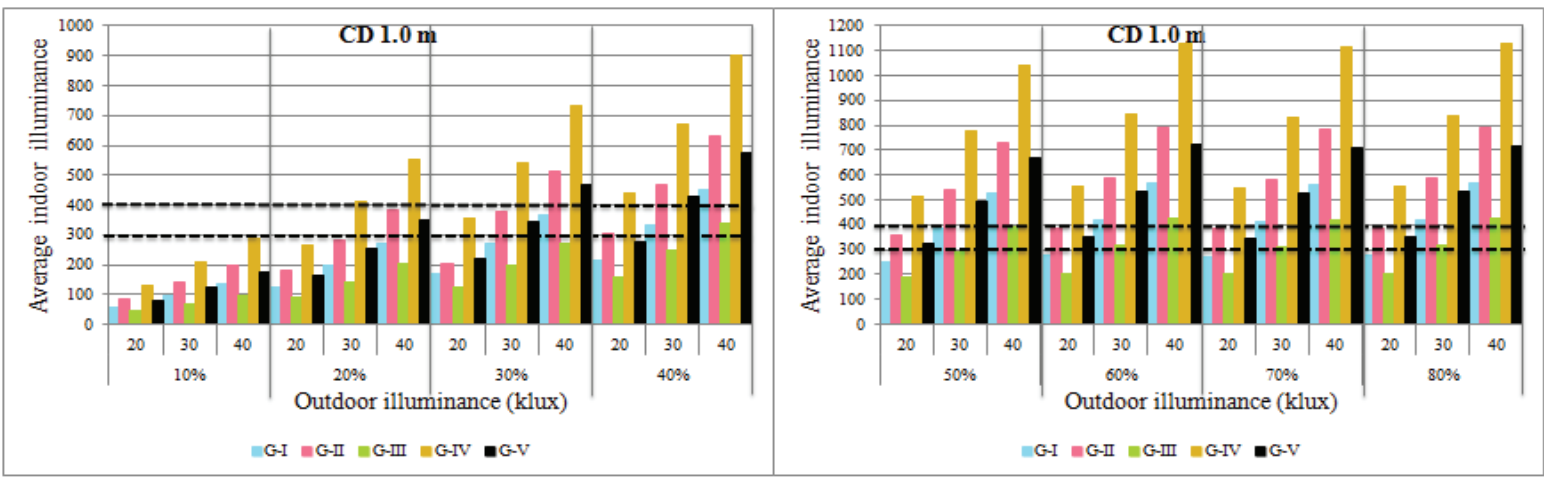

Fig 7: Average indoor illuminance versus outdoor illuminance $(20-40 \mathrm{klx})$ at different WWR and five types of implemented glazing window for CD 1.0m
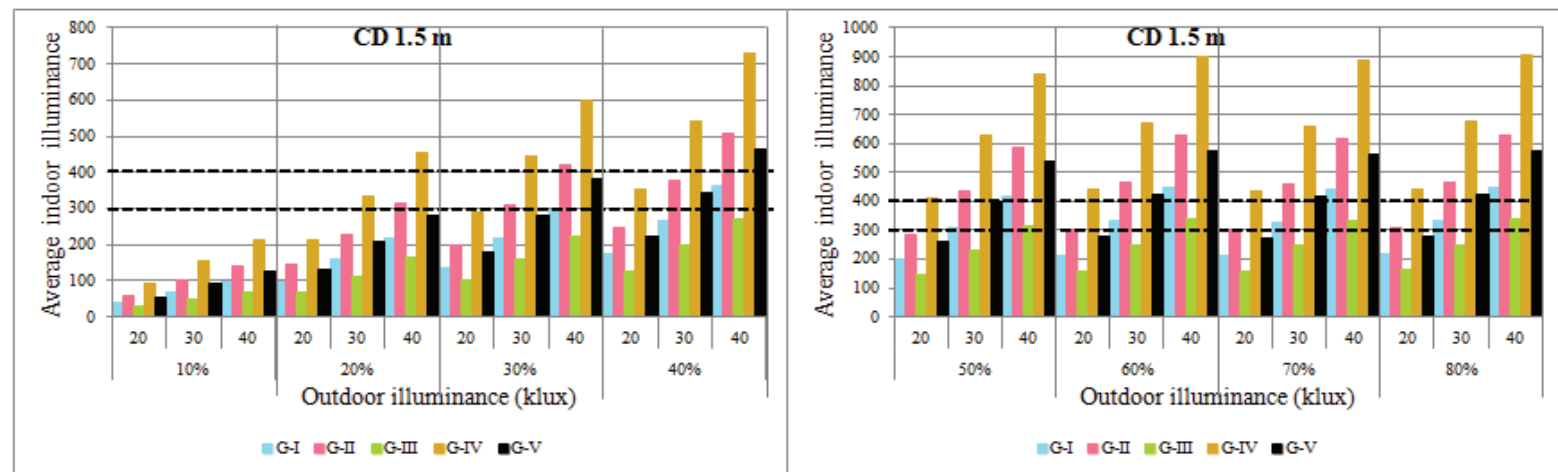

Fig 8: Average indoor illuminance versus outdoor illuminance (20-40klx) at different WWR and five types of implemented glazing window for CD $1.5 \mathrm{~m}$ 


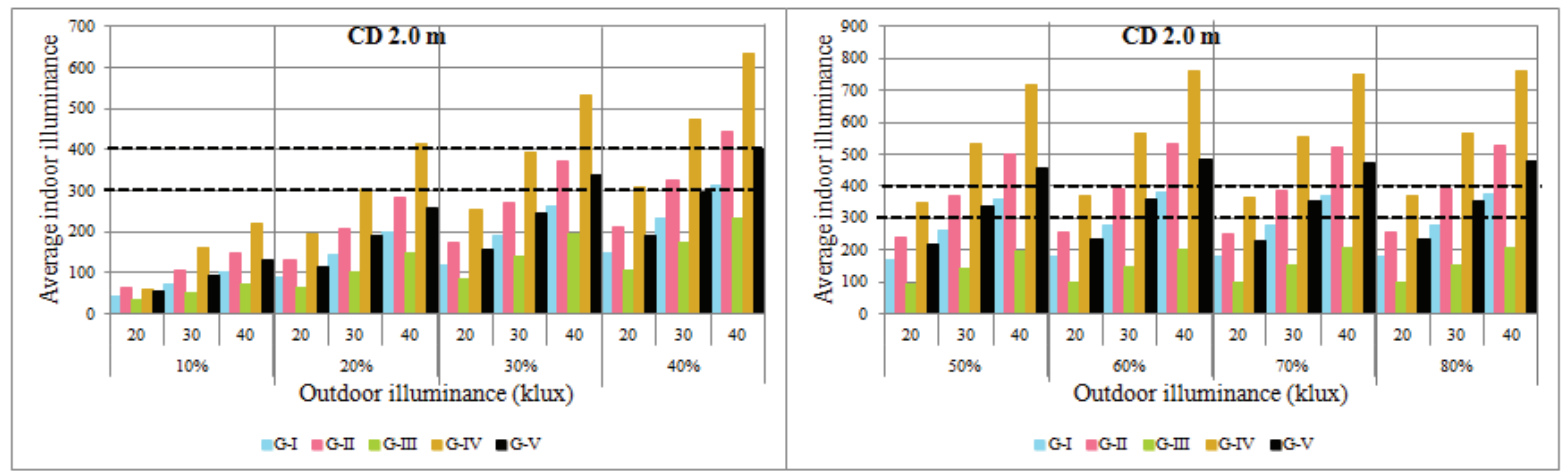

Fig 9: Average indoor illuminance versus outdoor illuminance (20-40klx) at different WWR and five types of implemented glazing window for CD $2.0 \mathrm{~m}$

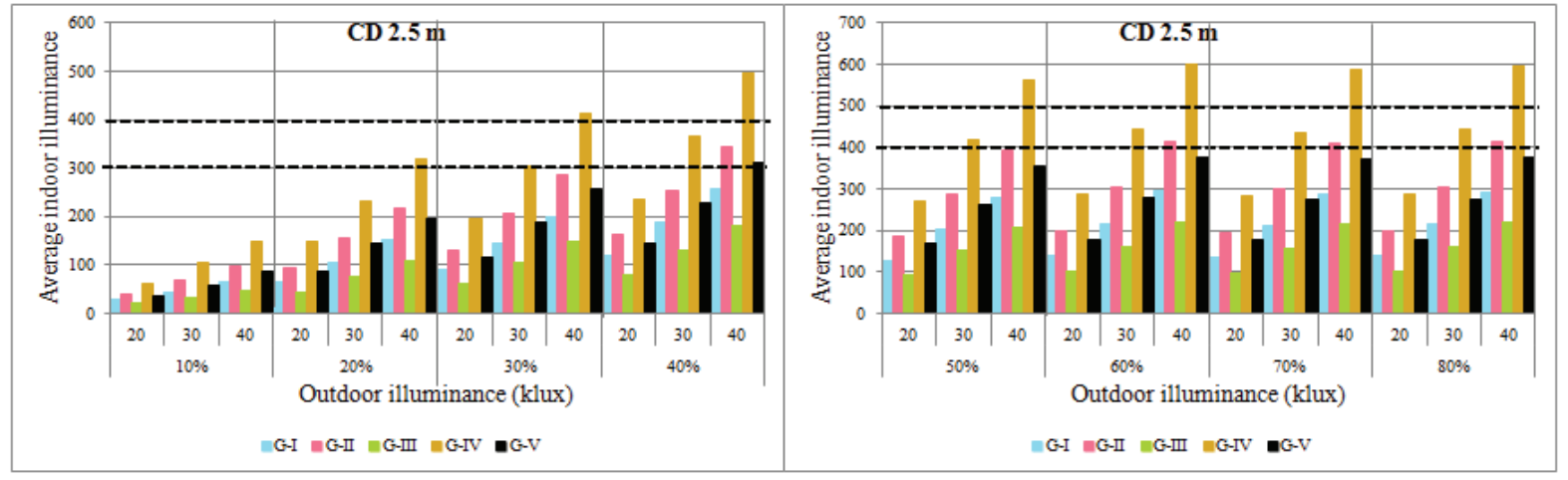

Fig 10: Average indoor illuminance versus outdoor illuminance (20-40klx) at different WWR and five types of implemented glazing window for CD $2.5 \mathrm{~m}$

As summarized in Table. 1, the DSF office with different glazing types are tested under outdoor illuminance range (20-40 klx) to determine the optimum glazing type for each CD. The optimum glazed type is the glazing that can supply the 2000 lux illuminance threshold near the window. It can be noted that, for a CD of $1.0 \mathrm{~m}$, the glazing type which is able to supply indoor illuminance close to $2 \mathrm{klx}$ near the window, is a (G-I) and (G-III), but with using (G-I), only in the area that has a depth of $10 \mathrm{~cm}$ near of the window of office, the indoor illuminance is more than $2000 \mathrm{~lx}$ while the remaining area of the office has a good quality of the indoor illuminance. At a CD of $1.5 \mathrm{~m}$, the best choice of window glazing must be used which has a transmittance around 58 and $53 \%$ such as (G-II) and (G-V). Finally, on account of the need of the office to high indoor illuminance at high cavity depth, the models require glazing window with high transmittance light, this clearly shows at a CD of 2.0 and $2.5 \mathrm{~m}$, therefore in this case, the best glazing window glazing must be used which has a transmittance around $82 \%$ such as (G-IV).

Table 1: Daylighting characteristics of the DSF office daylighting at different glazing types for different CDs under outdoor illuminance range (20-40 klx)

\begin{tabular}{|c|c|c|c|c|c|c|c|}
\hline \multirow[b]{2}{*}{$\begin{array}{l}\mathrm{CD} \\
(\mathrm{m})\end{array}$} & \multirow[b]{2}{*}{$\begin{array}{l}\text { Types } \\
\text { of } \\
\text { glazin } \\
\text { g }\end{array}$} & \multirow[b]{2}{*}{$\begin{array}{l}\text { Outdoor } \\
\text { illuminan } \\
\text { ce (klux) }\end{array}$} & \multirow{2}{*}{$\begin{array}{c}\text { Illuminan } \\
\text { ce level at } \\
\text { the area } \\
\text { near the } \\
\text { window }\end{array}$} & \multirow[b]{2}{*}{ Glare } & \multicolumn{3}{|c|}{ Space depth with } \\
\hline & & & & & $\begin{array}{c}100<\mathrm{UDI}<2000 \\
\operatorname{lux}\end{array}$ & $\begin{array}{c}\text { Illuminance } \geq 200 \\
\operatorname{lux} \\
(\mathrm{DF} \geq 2 \%)\end{array}$ & $\begin{array}{c}\text { Under-lit } \leq 199 \text { lux } \\
\text { DF }<2 \%\end{array}$ \\
\hline \multirow{5}{*}{1.0} & \multirow{3}{*}{ G-I } & 20 & 799 & $0 \%$ & $100 \%$ & $48 \%$ & $52 \%$ \\
\hline & & 30 & 1203 & $0 \%$ & $100 \%$ & $69 \%$ & $31 \%$ \\
\hline & & 40 & 1606 & $0 \%$ & $100 \%$ & $100 \%$ & $0 \%$ \\
\hline & \multirow{2}{*}{ G-II } & 20 & 1109 & $0 \%$ & $100 \%$ & $66 \%$ & $34 \%$ \\
\hline & & 30 & 1666 & $0 \%$ & $100 \%$ & $100 \%$ & $0 \%$ \\
\hline
\end{tabular}




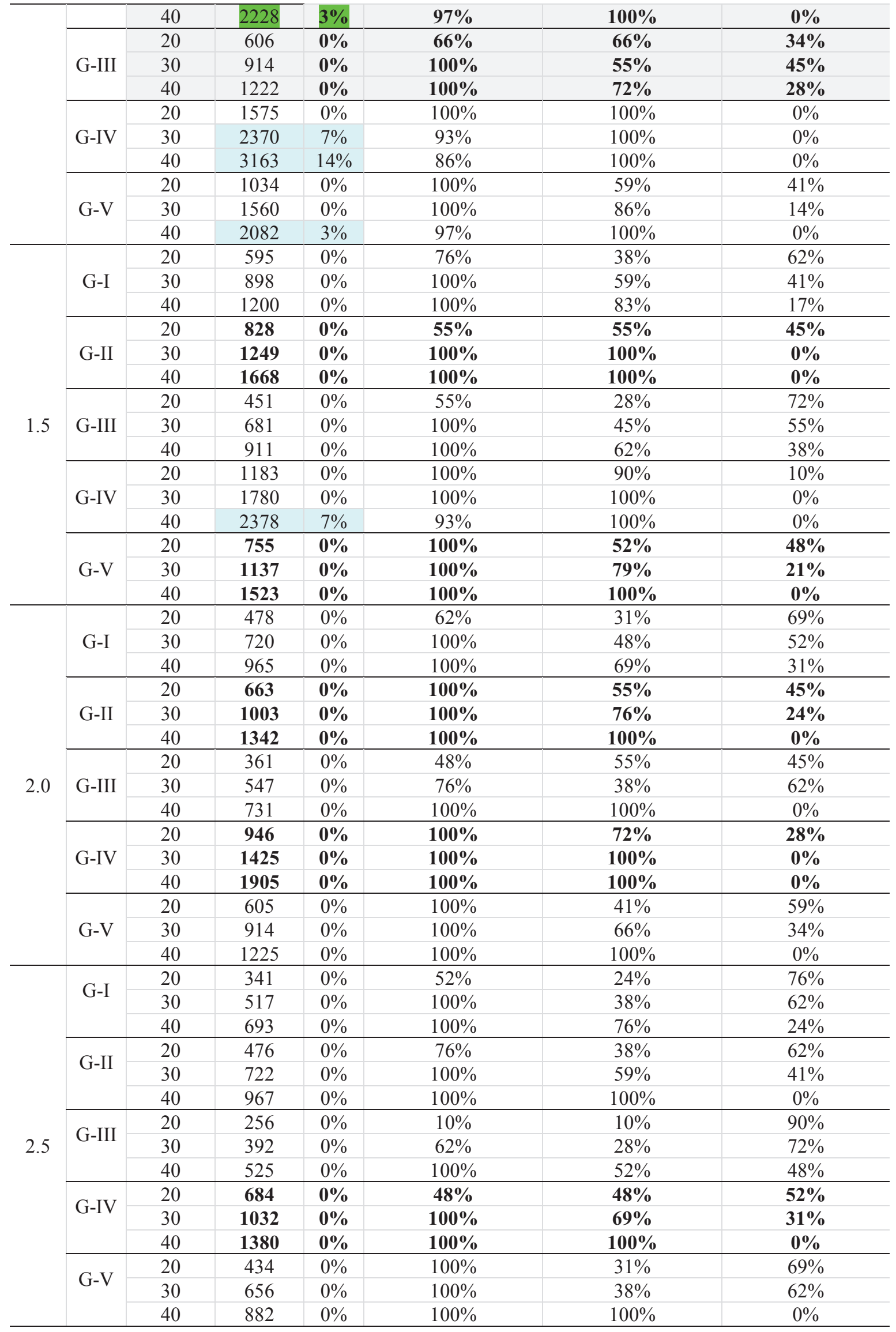




\section{Conclusions}

The amount of daylight that penetrates the window depends on the used glass type. The optimum WWR that should provide indoor illuminance inside the office without glare, maximum space within UDI, maximum space with an indoor illuminance of at least $200 \mathrm{~lx}$ is found $60-70 \%$. Increasing the cavity depth, causes decreasing the average indoor illuminance inside the office, therefore, this requires using glazing has a high transmittance for high outdoor illuminance. The optimum glazing type for the interior façade opening can be seen in the follow cases: At CD of $1.0 \mathrm{~m}$, the best choice of window glazing is that has a transmittance around $(32,42$ and 58) \%; At $\mathrm{CD}$ of $1.5 \mathrm{~m}$, the best choice of window glazing is that has a transmittance around (53 and 58) \%. Also, the best choice of window glazing for a $\mathrm{CD}$ of $2.0 \mathrm{~m}$ and $2.5 \mathrm{~m}$ is that has a transmittance around $82 \%$.

\section{References}

1. Ghaffarianhoseini A., Ghaffarianhoseini A., Berardi U., ToOKey J., Li D. H. W., Kariminia S. Exploring the advantages and challenges of double-skin façades (DSFs), Renewable and Sustainable Energy Reviews 2016: 60: 1052-1065.

2. Ahmed M. M., Abel-Rahman A. K., Ali A. H. H., Suzuki M. Double Skin Façade: The State of Art on Building Energy Efficiency, Journal of Clean Energy Technologies 2016: 4.

3. ZOMORODIAN Z. S., KorSAVI S. S., TAhSildoOst M. The effect of window configuration on daylight performance in classrooms: A field and simulation study, 24-15: 26: 2016:

4. Sripramong S., Ananwattanaporn S., NgaopitakKul A., JetTAnasen C. A Study an Impact of Daylight with Period Time on Illuminance and Uniformity for Building. Proceedings of the International MultiConference of Engineers and Computer Scientists; 2015.

5. GORGOLIS G., KARAMANIS D. Solar energy materials for glazing technologies, Solar Energy Materials and Solar Cells 2016: 144: 559-578.

6. Jelle B. P., Hynd A., Gustavsen A., Arasteh D., Goudey H., Hart R. Fenestration of today and tomorrow: A state-of-the-art review and future research opportunities, Solar Energy Materials and Solar Cells 2012: 96: 1-28.

7. Ghosh A., Norton B., Duffy A. Daylighting performance and glare calculation of a suspended particle device switchable glazing, Solar Energy 2016: 132: 114-128.

8. REINHART C. F. Effects of interior design on the daylight availability in open plan offices. 2002 ACEEE Summer Study on Energy Efficiency in Buildings; 2002, p. 309-322. 